\title{
貧困単身者とケアのゆくえ
}

\section{Single Poor People and Care}

\section{宮 本 みち子}

対人ケアは，家族の重要な機能であるが，それはますます得難いものになりつつある.

$\mathrm{NPO}$ 法人介護者サポートネットワークセンター・アラジンが 4,000 世帯を対象に, ケアラー がどのくらいいるかを調査している（平成22年度厚生労働省老人保健事業推進費等補助金. 家族（世帯）を中心とした多様な介護者の実態と必要な支援に関する調査研究事業）。この 調査で用いるケアの意味は広範囲で, 要介護高齢者や身体的・知的・精神的などの障がい者 の介護, 難病などの看病, 病児や障がい児の療育, 依存症やひきこもりなどの家族や知人の 世話や気づかいなど, 多様なケア役割を担っている人をケアラーと定義している. 調査結果 によれば，19.5\%の世帯にケアラーがいたほか，7.6\%の世帯には気づかいをしているケア ラーがいる．合計すると，5世帯に 1 世帯がケアラーのいる世帯である．ケアラーの 2 人に 1 人強は「介護」を，4人に 1 人は「看病」を， 8 人に 1 人は「子どもの療育」を， 5 人に 4 人は 「世話」を，7人に 5 人は「気づかい」など多様なケアを二重三重に行っている．ケアラーは, 健康状態や経済状態, こころの不調・負担感・孤立感などの問題を抱えている.

同居であれ別居であれ，ケアの担い手として家族が果たす役割は軽くなってはいないば かりか, 少子高齢化が進むなかでむしろ重くなっている場合もある．家族はどこまでその 負担に耐えることができるのだろうか.この調査によれば，現在ケアをしていない人の $84.5 \%$ 将来のケアへの不安を抱えている.

その一方で, 単身化の趨勢は高齢者にとどまらない，世代別の推移をみると，若い世代 ほど，早期に一人暮らし率が高まりをみせ，年齢が上がるにしたがってその率はいっそう 増加して, 中年期以後に単身で暮らす人が珍しくない社会へと突入している．単身者の多 くはどこかに身内がいるのだろうが，家族や身内をもたない，または疎遠になっている人 の数がじわじわと増加しているのはまちがいない，しかも，長期にわたる経済不況と格差 の拡大するなかで, 家庭をもつことのできない若年層, 不安定就業と貧困が直接の原因と なって家族崩壊を経験した中年から初老の人々が増加し, 単身化の原因となっていること に注意する必要がある，とくに男性の単身化はこれと深く結びついている.

家族福祉と「会社」福祉で成り立ってきた日本社会は，そこからはじき出された人々を 例外として扱ってきた。しかし，いまや例外と片付けられないほど単身化が進み，それら の人々を誰が引き受けるのかという問題に直面している。人工呼吸器と点滴チューブを付 けた病人が病室を追われて誰もいない自宅に帰らされる事態も生じているが，この問題は

Michiko Miyamoto: The Open University of Japan 


\section{JAPANESEJOURNALOFFAMIISOGLOLOGV}

貧しい人々のなかで抜き差しならない問題となっている．首都圈の例でいえば，生活保護 で暮らす身寄りのない高齢者が年々増加し，地方自治体の悩みとなっている．自力での生 活がおぼつかなくなった場合にどこが引き受けるのかという難問を抱えているのである.

受け皿としてもっぱら期待されているのが民間団体である．急成長しているNPO法人 SSS は, 身辺自立のできる生活保護受給高齢者の受け入れをし, 首都圏各地に 8,000 室を擁 するまでになった，首都圏の多くの自治体は，多数の生保受給者をこの施設に送ってい る. 食べること, 洗濯や掃除などを自力ではできなくなったらここにはいられないのだ が，その先は担保されていない，一方，身内のない一般高齢者は，お金でケアを手に入れ るしかない．こうしたニーズに応える各種のビジネスが急成長している．しかし，お金で 解決できるのはどこまでなのか, それに乗れない人々はどうなるのかに関しては十分に検 討されるいとまもなく，市場化が進んでいるようにみえる.

今, 低家賃の古い団地や木造アパートは, 家族のない中年から初老の男性のすまいとな り, 孤独死が発生しやすい場となっている。そこに住まう住人は, 隣室の住人が亡くなっ て異臭が漏れるようになるまで行動しょうとはしない. 失業, 病, 家族の喪失などを経験 し, 自ら社会関係を断ち切って生きている例が多いからである。家族縁を失った男性たち は，社会関係を作ろうという意欲を失っているという傾向が見られる.

くらしのセーフティネットとケア役割は, ジェンダー構造で成り立つ家族（ジェンダー家 族）に埋め込まれ，経済役割を果たす男とケア役割を果たす女という性別分業の正当性を政 治的に支えてきた（牟田2009）。ジェンダー家族を支えた社会経済構造が急速に変わるのに 対して, ケアを社会的に担保する取り組みは完全に遅れてしまった。とくに, 稼ぐ力によっ てケアラーとしての役割を妻に要求できた男性たちが, 稼ぐ力を失って孤立した単身者とな る例が増えているようにみえる。一方, ケア役割で男性の稼ぎの分配を交渉できた女性は, 男性が妻子を養う所得を稼ぐ条件を失ったとき，一気に貧困問題に直面している.

アメリカのジェンダー法学者, マーサ・ファイマン（2003）は，一対の男女の「性の絆」 からなる近代家族の耐用年数が，理論的にも実践的にも尽きてきたという認識のもとに， 性の絆よりケアの絆としての家族の再生を提唱している．子どもや，障がい者や高齢者の ケアをめぐる深刻な問題の噴出を前に, 性別役割分業の打破による新たな家族像（ジェン ダー平等家族）を求めるだけでは, これらの人々の救済はできないところにきている（上 野 2009). ここに, ケアという家族機能の再認識が登場するのであり, ケアの絆を前提と した家族支援政策が必要となるのである.

\section{【文献】}

ファイマン, マーサ, 上野千鶴子監訳, 2003, 『家族 積みすぎた方舟—ポスト平等主義のフェミ ニズム法理論』学陽書房.

牟田和恵, 2009,「ジェンダー家族のポリティクス」牟田和恵編『家族を超える社会学』新曜社, 67-89. 上野千鶴子, 2009, 「家族の臨界」牟田編, 同上書, 2-26. 